\author{
Praca poglądowa/Review paper
}

\title{
Napromienianie całego ciała TBI
}

\author{
Total Body Irradiation
}

\author{
Marta Paluszyńska, Justyna Schulz, Ewelina Konstanty \\ ${ }^{1}$ Zakład Radioterapii I, Wielkopolskie Centrum Onkologii, Poznań, Polska
}

\section{Streszczenie}

W Wielkopolskim Centrum Onkologii od dwudziestu pięciu lat stosuje się metodę napromieniania całego ciała (ang. Total Body Irradiation, TBI) jako metodę przygotowania pacjentów przed przeszczepem szpiku. Aktualnie stosowana procedura zakłada dawkę 12 Gy z obniżeniem dawki na płuca do 9 Gy. Pacjent jest napromieniany z pól lateralnych oraz kombinacji pól przednio-tylnych i tylno-przednich (ang. Anterior/ Posterior $A P / P A)$. Duża dawka, na którą eksponowany jest pacjent ma wpływ nie tylko na komórki nowotworowe, ale również na zdrowe narządy i prowadzi do licznych zmian popromiennych.

\begin{abstract}
The Total Body Irradiation (TBI) has been used at the Grater Poland Cancer Centre for twenty-five years as a method of preparing patients before bone marrow transplantation. The currently used procedure assumes a dose of 12 Gy with a lung dose reduction to 9 Gy. The patient is irradiated from lateral and AP / PA fields. The dose delivered to the patient affects not only cancer cells, but also healthy organs and leads to numerous post-radiation changes.
\end{abstract}

Stowa kluczowe: napromienianie całego ciała

Keywords: total body irradiation

Adres do korespondencji

Marta Paluszyńska

Zakład Radioterapii I,

Wielkopolskie Centrum Onkologii, ul. Garbary 15, 61-866 Poznań, Polska

Telefon. +488850543

e-mail: marta.paluszynska@wco.pl 


\section{Wstęp}

Przeszczep szpiku kostnego jest jedną z metod leczenia złośliwych nowotworów układu krwiotwórczego, takich jak ostra białaczka limfoblastyczna, ostra i przewlekła białaczka szpikowa, chłoniaki oraz chorób nienowotworowych takich jak anemia aplastyczna, wrodzona niedokrwistość, czy różnego rodzaju choroby metaboliczne. Białaczki charakteryzują się ilościowymi i jakościowymi zmianami białych krwinek we krwi, w szpiku oraz w narządach wewnętrznych chorych. Stanowią one około 2,5\% wszystkich nowotworów złośliwych. Najczęstszym typem białaczki jest przewlekła białaczka limfocytowa, która razem z białaczkami szpikowymi są chorobami wieku dorosłego. Ostra białaczka limfoblastyczna (ALL) jest najczęstszym nowotworem złośliwym u dzieci. Podstawowym celem przeszczepu jest odtworzenie zniszczonego przez terapię szpiku pacjenta. Terapia ma charakter skojarzony i obejmuje chemioterapię oraz radioterapię. Napromienianie całego ciała (ang. Total Body Irradiation, TBI) jest jedną z metod przygotowania pacjenta do przeszczepu szpiku i ma na celu zniszczenie szpiku pacjenta, komórek nowotworowych oraz wytworzenie immunosupresji, która ułatwia zagnieżdżenie się szpiku dawcy $[1,2]$.

\section{Total Body Irradiation}

Metoda napromieniania całego ciała rozwija się od początku XX-wieku, gdy w 1905 roku Frederic Dessauer zaprojektował urządzenie, które zapewniało jednorodny rozkład dawki promieniowania X w całym ciele, a terapia ta została wprowadzona do użytku klinicznego w 1923 roku przez Chaoula i Langa z Monachium, którzy wykorzystali ją na dwunastu pacjentach z chłoniakiem Hodgkina [2,4].

Głównym celem napromienia całego ciała jest podanie choremu wysokiej dawki promieniowania, która zniszczy komórki nowotworowe. Obszarem tarczowym podczas terapii jest szpik kostny, jednak dawką objęte jest całe ciało pacjenta. Źródło promieniowania początkowo stanowił kobalt Co-6o, który jednak z czasem został zastąpiony przez akceleratory liniowe generujące promieniowanie fotonowe oraz elektronowe. Wielkość dawki podanej pacjentowi na całe ciało zazwyczaj waha się od 12 Gy do 14,4 Gy z redukcją dawki na płuca i najczęściej podaje się ją w sześciu frakcjach, przez trzy dni. Podawanie dwóch frakcji dziennie wiąże się z koniecznością zachowania co najmniej 6-godzinnej przerwy pomiędzy nimi [2, 7, 10].

Jednym z najważniejszych zadań w przypadku tej techniki jest zachowanie jednorodnego rozkładu dawki w ciele pacjenta, co jest utrudnione przez nieregularny kształt ciała oraz różnice w gęstościach pomiędzy tkankami, czego typowym przykładem jest obszar płuc [2, 3]. Aby zapewnić jednorodny rozkład dawki w trakcie terapii stosuję się:

1. kombinację pól przednio-tylnych, tylno-przednich (ang. Anterior/Posterior AP/PA), bocznych (ang. Lateral) oraz dodatkowo wiązkę promieniowania elektronowego, w okolicy ściany klatki piersiowej [5-10];

2. bolusy wykonane z materiału tkankopodobnego w okolicy głowy, szyi, kolan i kostek, zapewniające podwyższenie dawki również na skórze pacjenta. W tym samym celu stosuje się również płytę z materiału tkankopodobnego ułożoną pomiędzy źródłem promieniowania, a pacjentem;

3. osłony indywidualne na płuca wykonane ze stopu Wood’a. W związku z tym, że osłaniają one również ścianę klatki piersiowej stosuje się promieniowanie elektronowe by dopromienić ten obszar. Kształt pola elektronowego definiowany jest przez osłony będące odwrotnością osłon na płuca [5-10].

\section{Powikłania występujące po napromienianiu całego ciała}

Wraz $\mathrm{z}$ podaniem pacjentowi wysokiej dawki frakcyjnej 2 Gy związane jest ryzyko poważnego uszkodzenia napromienianego narządu lub tkanki. Ważne jest więc pojęcie dawki tolerancji, czyli dawki, która powoduje dopuszczalny (do 5\% w przypadku większości narządów oraz do 1\% w przypadku rdzenia kręgowego) poziom uszkodzeń narządów w czasie 5 lat od przeprowadzenia procedury napromieniania. W tabeli 1 zostały przedstawione dawki tolerancji powodujące $5 \%\left(\mathrm{TD}_{5 / 5}\right)$ i $50 \%\left(\mathrm{TD}_{50 / 5}\right)$ uszkodzeń w czasie 5 lat od napromieniania dla niektórych narządów krytycznych [2]. Zakresy dawek przedstawione w tabeli 1 
zostały opracowane w sposób doświadczalny na podstawie wieloletnich obserwacji występowania odczynów wczesnych i późnych u chorych poddanych radioterapii z zastosowaniem standardowego frakcjonowania, czyli jednej frakcji dziennie. Stosowanie przyspieszonego schematu radioterapii (frakcja dwa razy dziennie) może się wiązać ze zwiększonych ryzykiem uszkodzenia zdrowych tkanek [2, 11].

Tabela 1. Dawki tolerancji dla narządów krytycznych dla pacjentów u których stosowano frakcjonowanie 2Gy dziennie przez 5 dni [2].

\begin{tabular}{|c|c|}
\hline Narząd krytyczny & ${\text { Dawka tolerancji } \mathbf{T D}_{5 / 5}-\mathbf{T D}_{50 / 5}}$ \\
\hline Rdzeń kręgowy & $54-70$ \\
\hline Mózg & $43-50$ \\
\hline Serce & $20-30$ \\
\hline Płuca & $23-28$ \\
\hline Nerka & $35-40$ \\
\hline Wątroba & $65-75$ \\
\hline Pęcherz & $1-2$ \\
\hline Jądra & $6-10$ \\
\hline Jajniki & $65-75$ \\
\hline Śluzówka & $6-12$ \\
\hline Soczewka & $65-70$ \\
\hline Kości & \\
\hline &
\end{tabular}

W przypadku dzieci niedojrzałe narządy są znacznie bardziej podatne na uszkodzenia niż ich odpowiedniki u dorosłych. Dlatego też u dzieci stosuje się niższe dawki frakcyjne, które nie przekraczają 2 Gy, czy nawet 1,5 Gy u dzieci poniżej trzeciego roku życia [2].

Ze względu na okres, w jakim mogą wystąpić skutki uboczne radioterapii dzielimy powikłania na wczesne oraz późne. Nudności, wymiotów i biegunki można się spodziewać u większości pacjentów po napromienieniu całego ciała dawką frakcyjną 2 Gy już po godzinie od rozpoczęcia procedury i mogą trwać do kilku dni po zakończeniu leczenia. Skutki te mogą być również związane z chemioterapią podawaną przed radioterapią. Często występują również podwyższona temperatury ciała, zmiany skórne, łysienie czy zapalenie śluzówek oraz suchość jamy ustnej. Mimo stosowania osłon służących do zmniejszenia dawki całkowitej, jaką otrzymują płuca i tak spotykane są powikłania ze strony układu oddechowego. Śródmiąższowe zapalenie płuc jest jedną z najczęstszych przyczyn zgonów po przeszczepie szpiku kostnego. Uszkodzenie wątroby u osób, które przeszły przeszczep szpiku kostnego może być zarówno związane z radioterapią jak i chemioterapią. Rozwija się ono w ciągu kilku tygodniu od terapii i objawia się wzrostem masy ciała, żółtaczką, bólem brzucha, powiększeniem wątroby, czy na przykład wodobrzuszem. Również tolerancja nerek na promieniowanie może być zmniejszona, gdy jednocześnie z radioterapią stosuje się chemioterapię i w późniejszym czasie może pojawić się u pacjentów zapalenie nerek. Szczególnie wrażliwe są nerki dzieci. Do narządów szczególnie wrażliwych należą również soczewki. Istnieje duże prawdopodobieństwo, bliskie 20\%, że w wyniku napromieniania u pacjentów rozwinie się zaćma. Im młodszy pacjent tym większe jest prawdopodobieństwo, że zostaną zaobserwowane zaburzenia w rozwoju oraz wielkości zębów. W przypadku układu nerwowego u pacjentów pojawia się senność z otępieniem, której można się spodziewać około sześciu tygodni po TBI. Stan ten jednak poprawia się samoistnie. Możliwe jest również uszkodzenie rdzenia kręgowego, ale występuje ono niezwykle rzadko. Dawki podczas napromieniania całego ciała mają również wpływ na funkcję gonad oraz płodność. Stopień upośledzenia narządów zależy od wieku, płci oraz dawki. U dorosłych kobiet najczęściej obserwowana jest niewydolność jajników z brakiem miesiączki oraz bezpłodność. U młodych kobiet może nastąpić nieznaczna regeneracja jajników w ciągu kilku lat po TBI. Możliwe jest również przejście wczesnej menopauzy. U mężczyzn najczęściej występuje bezpłodność. Badania natomiast wykazały, że bardzo młody wiek pacjentów może działać ochronnie na układ rozrodczy i ich proces dojrzewania zachodzi bez komplikacji [4]. 
U wielu pacjentów po zakończonym leczenia po latach następuje nawrót nowotworu. Ryzyko nawrotu nowotworu jest odwrotnie proporcjonalne do wieku pacjentów i bezpośrednio związane z czasem, który minął od leczenia, dawką promieniowania oraz pierwotnym nowotworem. Najczęściej spotykanymi nowotworami u osób, które przeszły napromienianie całego ciała są białaczki, guzy mózgu, jamy ustnej, tarczycy lub skóry $[2,4]$.

\section{Podsumowanie}

Napromienianie całego ciała skojarzone z chemioterapią wielolekową jest jedną z metod przygotowania pacjenta do przeszczepu szpiku kostnego w przypadku wielu rodzajów nowotworów złośliwych krwi. Od początku XX wieku metoda ta ciągle się zmienia, rozwija a sama procedura jest udoskonalana, aby zapewnić pacjentom większy komfort oraz ograniczyć występowanie skutków ubocznych terapii. W Wielkopolskim Centrum Onkologii metoda ta jest wykorzystywana od dwudziestu pięciu lat do leczenia pacjentów głównie zostrą białaczkąlimfoblastyczną, ale równieżwieloma innymi rozpoznaniami [10]. Aktualniewykorzystywany schemat leczenia to 12 Gy na całe ciało z redukcją dawki w płucach do 9 Gy. Dawka frakcyjna wynosi 2 Gy i jest podawana dwa razy dziennie z co najmniej 6-godzinną przerwą między frakcjami przez trzy dni. Pacjenci napromieniani są z pól bocznych oraz przednio-tylnych i tylno-przednich. Redukcja dawki w płucach jest możliwa dzięki zastosowaniu indywidualnie wykonanych na podstawie zdjęć tomografii komputerowej osłon ze stopu Wood'a, a w celu dopromienienia samej ściany klatki piersiowej wykorzystuje się promieniowanie elektronowe. Aby zapewnić jednorodny rozkład dawki w ciele pacjenta oprócz przedstawionej kombinacji pól, indywidualnych osłon oraz promieniowana elektronowego stosuje się również tkanokopodobne bolusy, dzięki którym możliwe jest zbudowanie dawki na skórze pacjenta.

\section{Konflikt interesu / Conflict of interest}

Nie występuje / None

\section{Piśmiennictwo / References}

[1] Skowrońska-Gardas A. Radioterapia w nowotworach wieku dziecięcego. Warszawa: Centrum Onkologii - Instytut im. M. Skłodowskiej-Curie, 2009.

[2] Konstanty E. Opracowanie i weryfikacja metody napromieniania całego ciała/szpiku akceleratorem tomoterapii spiralnej. Praca doktorska, Poznań 2013.

[3] Zwierzchowski G, Piotrowski T, Malicki J, Kosicka G. Rozkłady dawek podczas napromieniania całego ciała. Zeszyty Naukowe WCO 2006;3(2):47-63.

[4] Barrett A. Total Body Irradiation, Beatson Oncology Centre, Radiat Oncol, 5 April 2000.

[5] Malicki J, Kierzkowski J, Kosicka G, Górny A, Stryczyńska G, Wachowiak J. Obliczenia i weryfikacja pomiarowa rozkładów dawki w pacjencie poddanym frakcjonowanemu napromienianiu całego ciała. Nowotwory 1995;45(1):39-45.

[6] Malicki J, Kosicka G, Wachowiak J, Stryczyńska G. Ograniczenia praktyczne metody napromieniania całego ciała przed przeszczepieniem szpiku kostnego. Współcz Onkol 1997;1(2):43-4.

[7] Malicki J, Kosicka G, Wachowiak J, Stryczyńska G. Comparison of dose distribution in patient's body during all body irradiation in radiotherapeutic technique CO-60 and by X 15 MeV accelerator. Rep Pract Oncol Radiother 1999;4(4):116 .

[8] Malicki J. Does in Critical Organs during Total Body Irradiation before Bone Marrow Transplantation, Ann Transplant 1998;3(3):14-9.

[9] Malicki J, Kosicka G, Wachowiak J, Stryczyńska G, Kierzkowski J, Boruczkowski D. Dose distributions and early clinical results of patients with acute leukemia undergoing total body irradiation before allogeneic bone marrow transplantation. Nowotwory 1996;46(4):731-6,

[10] Kosicka G, Malicki J, Stryczyńska G, Wachowiak J, Boruczkowski D. 10 lat stosowania techniki TBI, czyli napromieniania całego ciała w Wielkopolskim Centrum Onkologii. Rep Pract Oncol Radiother 2003;8(2):209.

[11] Gasińska A. Biologiczne podstawy radioterapii, Kraków: Akademia Górniczo-Hutnicza im. ST. Staszica w Krakowie, Ośrodek Edukacji Niestacjonarnej, 2001. 